\title{
A Crucial Role for CAMP and Protein Kinase A in D1 Dopamine Receptor Regulated Intracellular Calcium Transients
}

\author{
Rujuan Dai Mohammad K. Ali Nelson Lezcano Clare Bergson \\ Department of Pharmacology and Toxicology, Medical College of Georgia, Augusta, Ga., USA
}

\section{Key Words}

Phospholipase $C \cdot$ Protein kinase A $\cdot$ Crosstalk $\cdot$ Priming .

$\mathrm{Gq} \cdot \mathrm{Gs} \cdot \mathrm{G}$ protein-linked receptor $\cdot \mathrm{IP}_{3}$

\begin{abstract}
D1-like dopamine receptors stimulate $\mathrm{Ca}^{2+}$ transients in neurons but the effector coupling and signaling mechanisms underlying these responses have not been elucidated. Here we investigated potential mechanisms using both HEK 293 cells that stably express D1 receptors (D1HEK293) and hippocampal neurons in culture. In D1HEK293 cells, the full D1 receptor agonist SKF 81297 evoked a robust dosedependent increase in $\mathrm{Ca}^{2+}{ }_{i}$ following 'priming' of endogenous $\mathrm{G}_{\mathrm{q} / 11}$-coupled muscarinic or purinergic receptors. The effect of SKF81297 could be mimicked by forskolin or 8-BrcAMP. Further, cholera toxin and the cAMP-dependent protein kinase (PKA) inhibitors, KT5720 and H89, as well as thapsigargin abrogated the D1 receptor evoked $\mathrm{Ca}^{2+}$ transients. Removal of the priming agonist and treatment with the phospholipase C inhibitor U73122 also blocked the SKF81297-evoked responses. D1R agonist did not stimulate $\mathrm{IP}_{3}$ production, but pretreatment of cells with the D1R agonist potentiated $\mathrm{G}_{\mathrm{q}}$-linked receptor agonist mobilization of intracellular $\mathrm{Ca}^{2+}$ stores. In neurons, SKF81297 and SKF83959, a partial D1 receptor agonist, promoted $\mathrm{Ca}^{2+}$ oscillations in response to $\mathrm{G}_{\mathrm{q} / 11^{1}}$-coupled metabotropic glutamate recep-
\end{abstract}

tor (mGluR) stimulation. The effects of both D1R agonists on the mGluR-evoked $\mathrm{Ca}^{2+}$ responses were PKA dependent. Altogether the data suggest that dopamine D1R activation and ensuing CAMP production dynamically regulates the efficiency and timing of $\mathrm{IP}_{3}$-mediated intracellular $\mathrm{Ca}^{2+}$ store mobilization.

Copyright ๑ 2008 S. Karger AG, Basel

\section{Introduction}

The $\mathrm{D} 1$ receptor $(\mathrm{D} 1 \mathrm{R})$ is one of five dopamine (DA) receptor subtypes expressed in brain [1]. D1Rs are enriched in the striatum, prefrontal cortex and hippocampus and play a key role in brain mechanisms linked to reward, learning, memory and movement via effects on inhibitory and excitatory transmission [2-5]. Albeit a Gslinked G protein-linked receptor (GPCR), behavioral studies revealed a perplexing discrepancy between the efficiency of various D1R agonists in stimulating adenylyl cyclase and the behavioral efficacy of these compounds in vivo [6]. Indeed, a series of studies have highlighted the ability of the D1R family of receptors, or a D1-like receptor to elevate intracellular $\mathrm{Ca}^{2+}\left(\mathrm{Ca}^{2+}{ }_{\mathrm{i}}\right)$ both in brain slices and neurons in culture [7-11]. In neurons, D1R agonists evoke a variety of $\mathrm{Ca}^{2+}$ responses ranging from immediate bursts detected within seconds, to delayed os-

\section{KARGER}

Fax +4161306 1234 E-Mail karger@karger.ch www.karger.com (c) 2008 S. Karger AG, Basel

$1424-862 X / 08 / 0163-0112 \$ 24.50 / 0$

Accessible online at:

www.karger.com/nsg
Clare M. Bergson

Department of Pharmacology and Toxicology, Medical College of Georgia 1459 Laney Walker Blvd

Augusta, GA 30912-2300 (USA)

Tel. +1 706721 1926, Fax +1 706721 2347, E-Mail cbergson@mail.mcg.edu 
cillations or gradual increases observed after several minutes.

In brain, $\mathrm{Ca}^{2+}{ }_{\mathrm{i}}$ levels regulate a number of intrinsic neuronal properties such as firing patterns, dendrite arborization, as well as neurotransmitter release, receptor trafficking, gene transcription and synaptic plasticity [12-16]. While D1R-mediated DA transmission appear to modulate many of these responses, the signaling mechanisms underlying the ability of D1R agonists to rapidly elevate $\mathrm{Ca}^{2+}{ }_{i}$ levels and/or stimulate $\mathrm{Ca}^{2+}$ oscillations are not known. There are clear indications that in brain, crosstalk with $\mathrm{G}_{\mathrm{q} / 11^{-}}$-linked receptors might account for at least some of the neuromodulatory actions of D1Rs. For example, D1R activation potentiates $\mathrm{G}_{\mathrm{q} / 11}$ receptor-induced $\mathrm{Ca}^{2+}$ waves spreading across the developing frontal cortex [17]. Likewise, an earlier study of adult prefrontal cortex indicated that DA induces long-term synaptic depression in the context of $\mathrm{G}_{\mathrm{q} / 11}$-linked glutamate receptor co-activation [18]. On the other hand, several studies posit the existence of a PLC-linked D1-like receptor [11, 19, 20]. Here, we explore both arms of the cAMP and $\mathrm{Ca}^{2+}{ }_{\mathrm{i}}$ signaling cascades in detail to better understand the mechanisms underlying the $\mathrm{Ca}^{2+}{ }_{i}$ transients regulated by D1R agonists in neurons. Our results point to mechanisms involving cAMP and PKA activation.

\section{Materials and Methods}

Cell Culture, DNA Constructs, and Reagents

HEK293 cells were cultured in Dulbecco's modified Eagle's medium (DMEM; Invitrogen, Carlsbad, Calif., USA), supplemented with $10 \%$ fetal calf serum (FCS; Mediatech, Herndon, Va., USA). The human D1R stable cell line (D1HEK293) [21] was maintained in DMEM medium containing $250 \mu \mathrm{g} / \mathrm{ml}$ G418 (Sigma, St. Louis, Mo., USA). Carbachol, SKF81297, SKF38959, forskolin, H89, atropine, and 8-Br-cAMP were purchased from Sigma. ATP was obtained from Roche Applied Sciences. Cholera toxin (CTX) was purchased from Research Biochemical International (Sigma) and pertussis toxin (PTX) from List Biological Laboratories (Campbell, Calif., USA). Thapsigargin, U73122, DHPG, and KT5720 were obtained from Tocris (Ellisville, Mo., USA).

\section{Ratiometric $\mathrm{Ca}^{2+}$ Imaging}

D1HEK293 cells or hippocampal neurons were plated in polyD-lysine coated cover-slip bottom dishes (MatTek, Ashland, Mass., USA) and loaded at $37^{\circ} \mathrm{C}$ for $40 \mathrm{~min}$ with $5 \mu \mathrm{M}$ Fura-2 AM (Molecular Probes, Eugene, Oreg., USA), dissolved in DMSO with $2.5 \%$ pluronic acid and diluted with $\mathrm{HBS}$ (in $\mathrm{mM}$ : Hepes, $10 ; \mathrm{NaCl}, 150 ; \mathrm{MgCl}_{2}, 2 ; \mathrm{KCl}, 2.5 ; \mathrm{CaCl}_{2}, 4$; glucose, 10), $\mathrm{pH}$ 7.4. Cells were then washed three times with HBS, and bathed in HBS for $15 \mathrm{~min}$ at $37^{\circ} \mathrm{C}$ before $\mathrm{Ca}^{2+}$ imaging at room temperature. For studies performed in $\mathrm{Ca}^{2+}$-free HBS (in mM: Hepes, $10 ; \mathrm{NaCl}$, 150; $\mathrm{MgCl}_{2}, 8 ; \mathrm{KCl}, 2.5$; EGTA 0.25; glucose, 10), cells were washed three times with $\mathrm{Ca}^{2+}$-free $\mathrm{HBS}$ and bathed in $\mathrm{Ca}^{2+}$-free HBS after loading with Fura-2 in $\mathrm{Ca}^{2+}$-containing HBS. Samples were viewed with Zeiss Axiovert S100 microscope using a $40 \times$ oil immersion objective, and sequentially illuminated with a $100 \mathrm{~W}$ Xenon monochrometer at $10 \mathrm{~s}$ (D1HEK293 cells) or 1-3 s (hippocampal primary cultures) intervals for 20-40 ms, first at $340 \mathrm{~nm}$, and then at $380 \mathrm{~nm}$. Images were collected via a CCD camera (Imago QE) connected to a Dell workstation. Fluorescence emission at $510 \mathrm{~nm}$ was monitored for each excitation wavelength, and analyzed with TillVision software (TillPhotonics, Germany). Pixel intensities within selected areas of the images (with each area corresponding to a single cell) were digitized for both wavelengths at each time point. The first ten data points were averaged to establish $\mathrm{F}_{0}$, the baseline ratio of emission detected at $510 \mathrm{~nm}$ following excitation at 340 and $380 \mathrm{~nm}\left(\mathrm{~F}_{340} /\right.$ $\mathrm{F}_{380}$ ). Changes in $\mathrm{F}_{340} / \mathrm{F}_{380}$ with time were plotted as $\mathrm{F}-\mathrm{F}_{0} / \mathrm{F}_{0}$. The $\mathrm{Ca}^{2+}{ }_{\mathrm{i}}$ traces shown are representative results obtained in at least three independent experiments, and typically correspond to the mean response detected in 12-15 randomly selected cells (unless noted otherwise).

\section{Measurement of $\mathrm{IP}_{3}$ by Ion Exchange Chromatography}

Inositol phosphate measurements were carried out following the method described by Islam and Akhtar [22] with some modifications. Briefly, D1HEK 293 cells were seeded at $50 \%$ confluence in poly-L-lysine coated 6-well plastic dishes. After 20-24 h, the medium was removed and cells were rinsed (using PBS) and starved for another $24 \mathrm{~h}$ in inositol and serum-free medium containing $18-20 \mu \mathrm{Ci} /$ well myo- $\left[2-{ }^{3} \mathrm{H}\right]$ inositol (Amersham Biosciences) and 2\% BSA (Sigma). The cells were washed in PBS to remove the unincorporated radioactivity, and equilibrated with inositol-free medium containing $10 \mathrm{~mm}$ lithium chloride for $20 \mathrm{~min}$ at $37^{\circ} \mathrm{C}$. Agonist stimulation of D1HEK293 cells was carried out at RT with $50 \mu \mathrm{M}$ carbachol and/or $10 \mu \mathrm{M}$ SKF81297. After stimulation, cells were placed on ice and the medium replaced with $1.5 \mathrm{ml}$ of ice-cold $1 \mathrm{M}$ formic acid. Cell lysates were harvested after $10 \mathrm{~min}$ incubation on ice by scraping with a rubber policeman, and sonicated. Supernatants were collected following centrifugation at 14,000 rpm for $1 \mathrm{~min}$, and aliquots retained for protein concentration determination. Equal volumes of the cell supernatants were applied to Dowex AG1X8 (BioRad) ion exchange columns equilibrated with $1 \mathrm{M}$ formic acid. The columns were washed with 50 bed volumes of de-ionized water, and bound $\mathrm{IP}_{1}, \mathrm{IP}_{2}$ and $\mathrm{IP}_{3}$ sequentially eluted with $0.2,0.4$ and $1.0 \mathrm{M}$ ammonium formate, respectively. Levels of eluted isotope were determined by scintillation counting (Beckman Instruments).

\section{Neuronal Cultures}

Neuronal cultures were prepared from postnatal day 2-4 Sprague-Dawley rat pups. Briefly, hippocampi dissected from ketamine-injected ( $3 \mathrm{mg} / \mathrm{pup}$, intraperitoneal) rat pups were dissociated for $2 \mathrm{~h}$ in the presence of $20 \mathrm{U} / \mathrm{ml}$ activated papain. Dissociated cells were plated into glass bottom dishes coated with 100 $\mu \mathrm{g} / \mathrm{ml}$ poly-D-lysine and $5 \mu \mathrm{g} / \mathrm{ml}$ laminin at a density of approximately 600,000 cells per dish. Neuronal medium conditioned over glia was used to maintain the cultures. Experiments were performed with cultures at 7-18 DIV. 

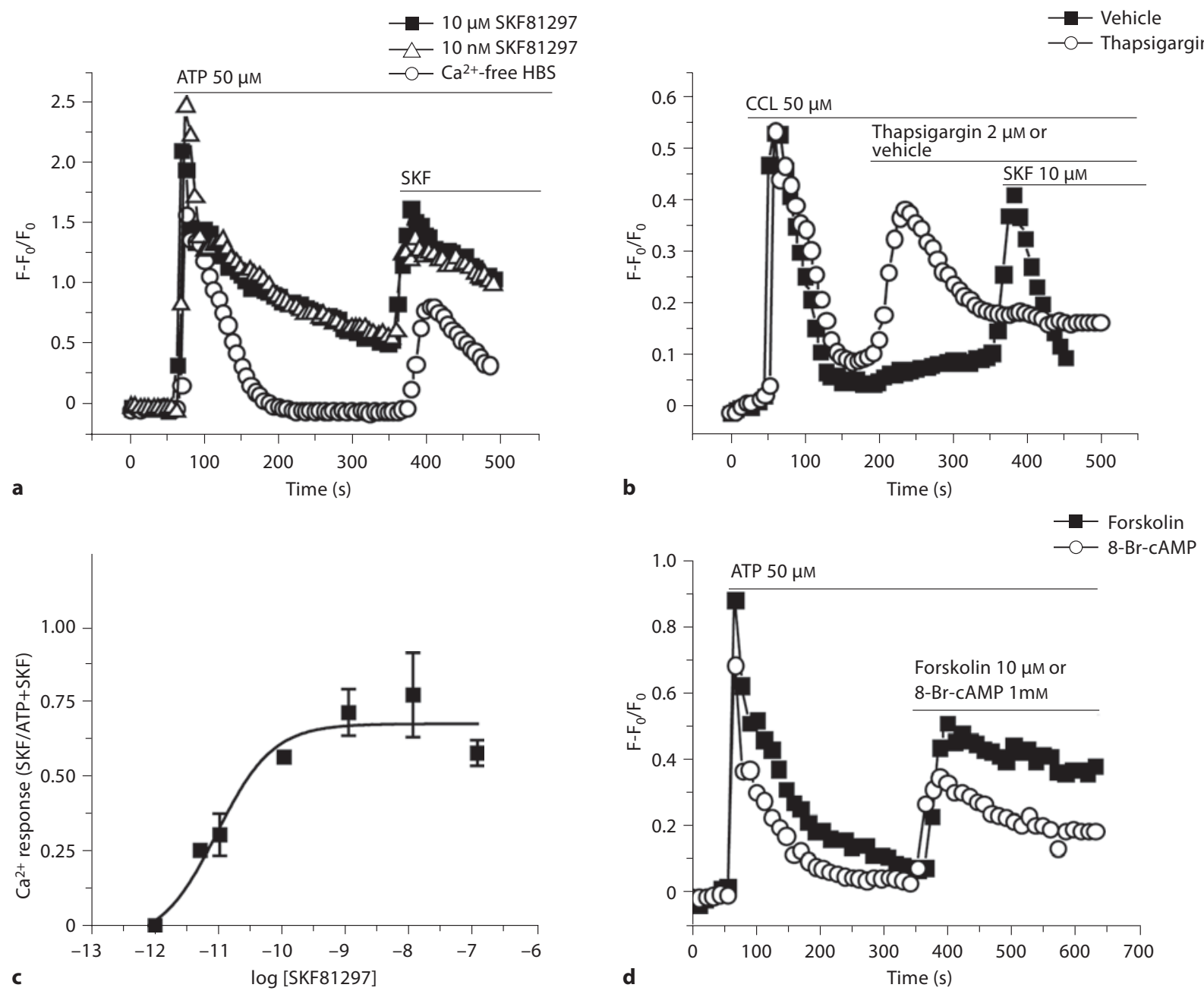

Fig. 1. D1R-evoked $\mathrm{Ca}^{2+}$ transients in D1HEK293 cells. a D1Revoked $\mathrm{Ca}^{2+}$ responses in D1HEK293 cells stimulated with either $10 \mathrm{nM}$ or $10 \mu \mathrm{M}$ SKF81297 in $\mathrm{Ca}^{2+}$-containing HBS. ATP- $(50 \mu \mathrm{M})$ and SKF $(10 \mu \mathrm{M})$-evoked $\mathrm{Ca}^{2+}$ responses in $\mathrm{Ca}^{2+}$-free HBS solution. Cells were first stimulated with ATP; SKF 81297 was added to the bath when the ATP-evoked $\mathrm{Ca}^{2+}$ response returned to baseline. $\mathbf{b}$ Addition of thapsigargin, but not vehicle, after priming occluded the D1R-stimulated $\mathrm{Ca}^{2+}$ responses. c Dose-response curve in which the integrated area of the $\mathrm{Ca}^{2+}$ transient evoked by SKF81297 (final concentrations ranging from $1 \mathrm{pM}$ to $100 \mathrm{nM}$; $\mathrm{n}=2-9$ independent replicates involving $6-8$ cells each). The size of the SKF-evoked response is represented here as the fraction of the total $\mathrm{Ca}^{2+}$ response $(\mathrm{SKF} /(\mathrm{ATP}+\mathrm{SKF}))$ in each experiment. d Forskolin $(10 \mu \mathrm{M})$-evoked $\mathrm{Ca}^{2+}$ transients following priming of D1HEK293 cells. Application of the cell permeant cAMP analog, 8 -Br-cAMP (1 mM), also robustly stimulated $\mathrm{Ca}^{2+}{ }_{\mathrm{i}}$ release after priming.

Fig. 2. D1R-evoked $\mathrm{Ca}^{2+}$ transients involve coupling to $\mathrm{Gs}$ and stimulation of adenylyl cyclase. a Lack of SKF-evoked $\mathrm{Ca}^{2+}$ responses in D1HEK293 cells pretreated with $2 \mu \mathrm{g} / \mathrm{ml}$ cholera toxin (CTX), but not with100 ng/ml pertussis toxin (PTX) or vehicle. Cells were incubated with toxins or vehicle for $16 \mathrm{~h}$ prior to loading with Fura-2 AM. b Responses of PTX- and CTX-treated cells to $\mathrm{SKF}$ are shown as the net change in $\mathrm{F}_{340} / \mathrm{F}_{380}$. Inset, isoproterenol (ISO) $(10 \mu \mathrm{M})$ activating endogenous $\beta$-adrenergic receptors stimulates $\mathrm{Ca}^{2+}$ i release when applied after ATP or CCL (not shown). c, d Pretreatment of D1HEK293 cells with the PKA inhibitor KT5720 $(1 \mu \mathrm{M})$, but not vehicle, inhibited the SKF-evoked $\mathrm{Ca}^{2+}$ responses. e, f The PKA inhibitor H89 $(50 \mu \mathrm{M})$ also significantly blocked production of the D1R agonist-evoked $\mathrm{Ca}^{2+}$ responses. For, $\mathbf{d}$ and $\mathbf{f}$, responses to SKF (or CCL in $\mathbf{f}$ ) are shown as the net change in $\mathrm{F}_{340} / \mathrm{F}_{380}$. Bars correspond to the means $\pm \mathrm{SEM}$, $\mathrm{n}=3-6$ independent experiments, with ${ }^{* *} \mathrm{p}<0.01$ determined by two population-independent $t$ tests. 

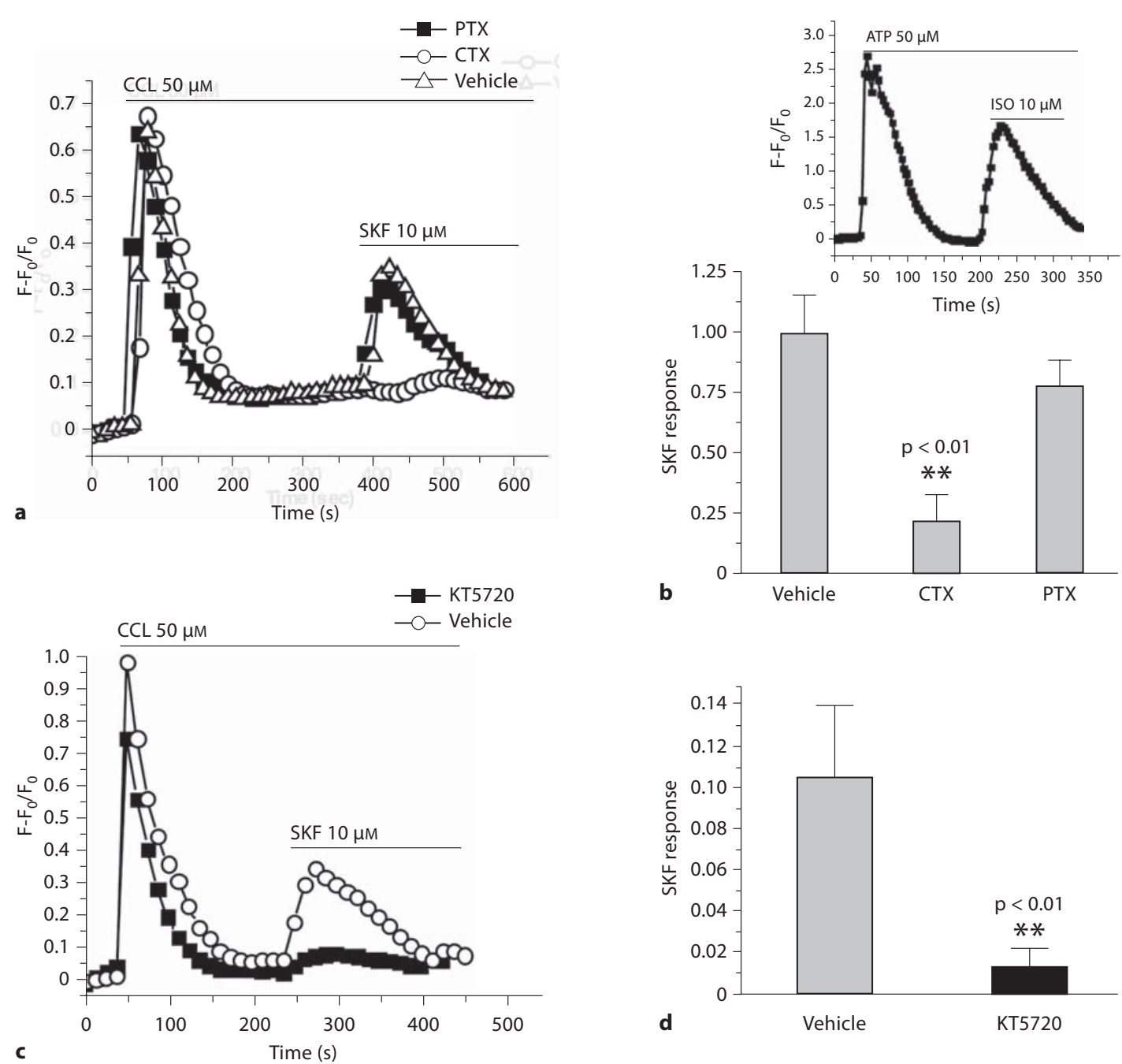
Time (s)
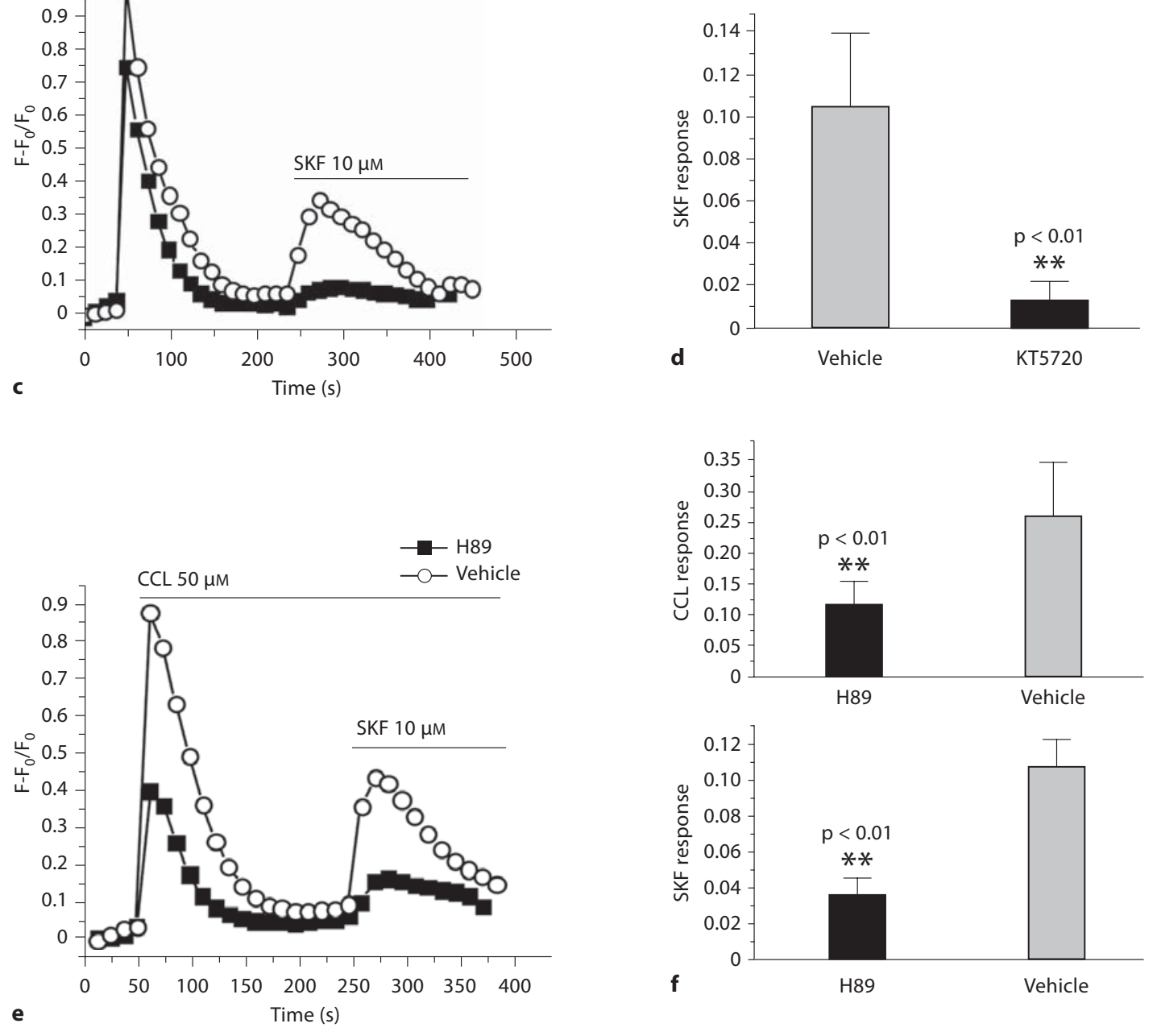


\section{Results}

\section{D1Rs Stimulate $\mathrm{Ca}^{2+}{ }_{i}$ Release following Activation of} Gq-Coupled GPCRs

Activation of endogenous Gs-linked D1-like DA receptors (D1 and D5R) rapidly elevates $\mathrm{Ca}^{2+}{ }_{\mathrm{i}}$ levels in hippocampal and neocortical neurons provided that the cells are 'primed' with agonists of Gq-linked GPCRs [8]. To pinpoint the signaling mechanisms involved, we investigated D1/5R agonist-evoked $\mathrm{Ca}^{2+}$ transients in D1HEK293 cells, a cell line stably expressing D1Rs [21]. Application of either ATP $(50 \mu \mathrm{M})$ or carbachol (CCL, 50 $\mu \mathrm{M})$ to activate endogenous $\mathrm{G}_{\mathrm{q}}$-linked purinergic or muscarinic receptors, respectively, evoked large $\mathrm{Ca}^{2+}{ }_{i}$ transients in the D1HEK293 cells (fig. 1a, b). Subsequent addition of the D1/5R agonist SKF $81297(10 \mu \mathrm{M})$ also evoked robust $\mathrm{Ca}^{2+}$ transients (fig. 1a, b). Extracellular $\mathrm{Ca}^{2+}$ $\left(\mathrm{Ca}^{2+}{ }_{e}\right)$ was not essential for the D1R-evoked responses as the $\mathrm{Ca}^{2+}$ transients were only slightly smaller with respect to initial amplitude, and faster in returning to baseline when cells were stimulated in $\mathrm{Ca}^{2+}$-free compared to $\mathrm{Ca}^{2+}$-containing medium (fig. 1a). Further, the efficacy of thapsigarin $(2 \mu \mathrm{M})$ in occluding both the ATP (data not shown) as well as the subsequent D1R-evoked $\mathrm{Ca}^{2+}{ }_{\mathrm{i}}$ transients suggested both types of responses involved release of $\mathrm{Ca}^{2+}$ from the smooth endoplasmic reticulum (SER) (fig. 1b).

Although the application of 10 nM SKF81297 evoked a $\mathrm{Ca}^{2+}$ transient similar in size to that evoked by $10 \mu \mathrm{M}$ SKF81297 (fig. 1a) ( $p=0.7$; t test), we examined the dose dependence of the SKF-evoked $\mathrm{Ca}^{2+}$ response with a further series of dilutions. Indeed, the levels of intracellular $\mathrm{Ca}^{2+}$ mobilized by SKF81297 in D1HEK293 cells increased in a dose dependent fashion, showing an $\mathrm{EC}_{50}$ value of $44 \mathrm{pm}$ (fig. 1c).

\section{Essential Role of the Gs/cAMP/PKA Pathway in}

D1R-Evoked $\mathrm{Ca}^{2+}$ Transients

SKF81297 is a full agonist of Gs-linked D1Rs [6]. Therefore, we tested whether adenylyl cyclase coupling was crucial for $\mathrm{Ca}^{2+}$ mobilization. Results obtained with forskolin, a direct activator of adenylyl cyclase, strongly indicated that cAMP signaling plays a key role in the magnitude of the D1R-stimulated $\mathrm{Ca}^{2+}$ responses. When applied to D1HEK293 cells after priming with either ATP or CCL, forskolin $(10 \mu \mathrm{M})$ appeared to fully mimic the effect of SKF81297 (fig. 1d). Application of the cell permeant cAMP analog, 8-Br-cAMP (1 mM) also elicited a robust $\mathrm{Ca}^{2+}$ response when applied to D1HEK293 cells after priming (fig. 1d).
We then examined the role of heterotrimeric $\mathrm{G}$ protein coupling in the D1R-evoked $\mathrm{Ca}^{2+}$ responses using cholera toxin (CTX) or pertussis toxin (PTX), agents that result in the uncoupling of agonist-stimulated receptor signaling through $\mathrm{G}_{\mathrm{s}}$ and $\mathrm{G}_{\mathrm{i}}$, respectively. Pretreatment with CTX $(2 \mu \mathrm{g} / \mathrm{ml})$, but not PTX $(100 \mathrm{ng} / \mathrm{ml})$ abrogated detection of the D1R agonist-evoked $\mathrm{Ca}^{2+}$ responses (fig. 2a, b). In contrast, neither CTX nor PTX inhibited the priming receptor-evoked $\mathrm{Ca}^{2+}$ responses. Taken together, the results of the CTX, forskolin, and 8Br-cAMP studies strongly supported the idea that adenylyl cyclase activation is a necessary step in the crosstalk dependent mechanism by which D1Rs stimulate $\mathrm{Ca}^{2+}{ }_{\mathrm{i}}$ transients. Consistent with this notion, application of isoproterenol $(10 \mu \mathrm{M})$, an agonist of endogenously expressed $\beta$-adrenergic receptors ( $\beta A R s)$ [23] to D1HEK293 cells primed with ATP $(50 \mu \mathrm{M})$ also evoked robust $\mathrm{Ca}^{2+}$ responses (fig. $2 \mathrm{~b}$, inset). Further, pretreatment of cells with the selective PKA inhibitor, KT5720 $(1 \mu \mathrm{M})$ fully inhibited the ability of SKF (fig. 2c, d) and forskolin (data not shown). H89 (50 $\mu \mathrm{M})$, another PKA inhibitor, also blocked the SKF $\mathrm{Ca}^{2+}$ responses, but in addition, partially inhibited the primary receptorevoked $\mathrm{Ca}^{2+}$ transients (fig. 2e, f).

Fig. 3. Ongoing phospholipase C (PLC) activity is required for D1R and forskolin-potentiated $\mathrm{Ca}^{2+}{ }_{\text {i }}$ release. a D1HEK293 cells were perfused with HBS to wash out the priming agonist ATP, and then stimulated with either $10 \mu \mathrm{M}$ SKF or $10 \mu \mathrm{M}$ forskolin. b, c Addition of the muscarinic antagonist, atropine, after priming with carbachol (CCL) blocked $\mathrm{Ca}^{2+}$ responses to SKF even in the continued presence of CCL. However as shown in c, SKF stimulated $\mathrm{Ca}^{2+}$ responses in atropine-treated cells if applied after ATP. d Addition of the PLC inhibitor U73122, but not vehicle (DMSO) blocked the ability of forskolin (not shown) or SKF81297 $(10 \mu \mathrm{M})$ to stimulate $\mathrm{Ca}^{2+}{ }_{\mathrm{i}}$ release. Horizontal lines reflect the periods where indicated drugs were present in the bath. Experiments shown in $\mathbf{a}$ and $\mathbf{b}$ were performed in $\mathrm{Ca}^{2+}$-containing medium (however, similar results were obtained in $\mathrm{Ca}^{2+}$-free medium), and $\mathbf{c}$ and $\mathbf{d}$ in $\mathrm{Ca}^{2+}$-free HBS. e Inositol phosphate levels measured by ion exchange chromatography at time points indicated for each treatment. D1HEK293 cells were stimulated with $50 \mu \mathrm{M}$ CCL (CCL) or $10 \mu \mathrm{M}$ SKF81297 (SKF) added at time $(\mathrm{t})=$ 0 , or $50 \mu \mathrm{M}$ CCL added at $\mathrm{t}=0$ and $10 \mu \mathrm{M} \mathrm{SKF} 81297$ at $\mathrm{t}=5 \mathrm{~min}$ (CCL/SKF). Alternatively, cells were not treated with agonists (HBS). Data shown represents the average between two independent experiments performed in triplicate. 


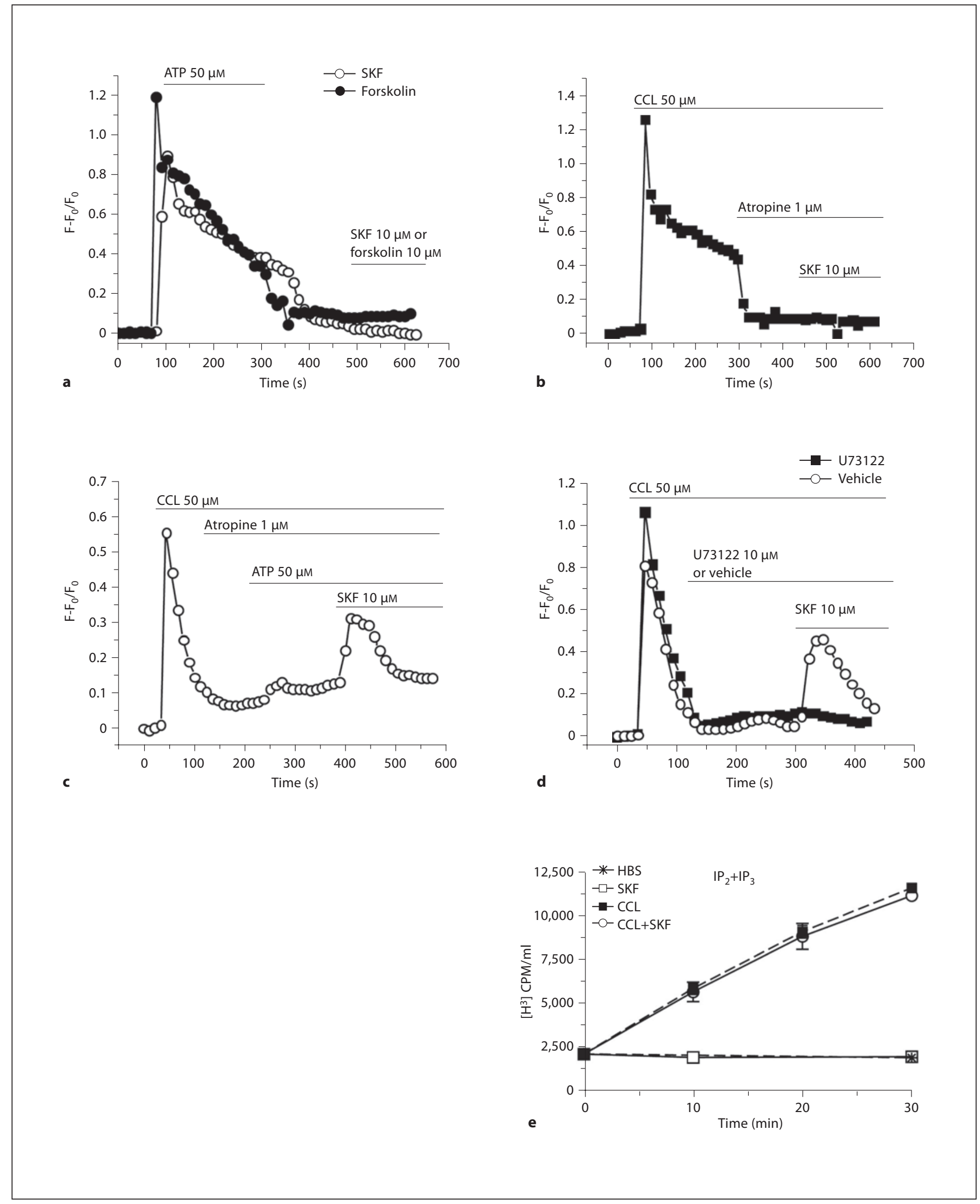




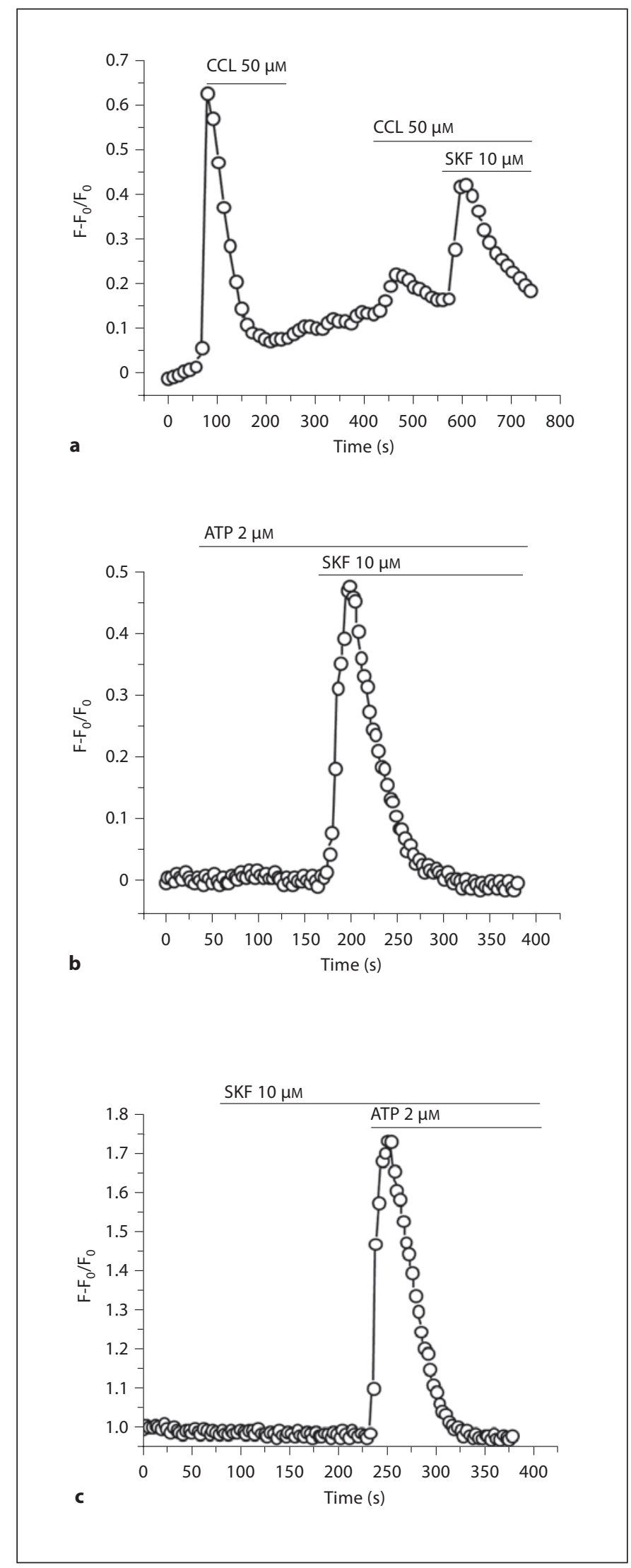

118
Continuous Phospholipase C Activity and $G_{s}$-Linked GPCR Stimulated $\mathrm{Ca}^{2+}$ Release

Continued $\mathrm{G}_{\mathrm{q}}$-coupled receptor stimulation was critical for the D1R- and forskolin-evoked $\mathrm{Ca}^{2+}$ spikes. That is, neither SKF- nor forskolin-evoked detectable $\mathrm{Ca}^{2+}$ responses in cells perfused with HBS after brief P2YR stimulation (fig. 3a). Similarly, application of atropine (1 $\mu \mathrm{M})$ after CCL quenched the CCL response, and also blocked the ability of SKF to stimulate a $\mathrm{Ca}^{2+}$ response (fig. $3 \mathrm{~b}$ ). However, ATP, when added after atropine, rescued the ability of SKF to evoke $\mathrm{Ca}^{2+}$ transients (fig. 3c). Further, application of the phospholipase C (PLC) inhibitor U73122 $(10 \mu \mathrm{M})$, but not vehicle to D1HEK293 cells after priming, blocked the ability of both SKF (fig. 3d) and forskolin (not shown) to evoke $\mathrm{Ca}^{2+}{ }_{i}$ release. Altogether, these results indicated that concurrent PLC stimulation by a $G_{q / 11}$-linked GPCR is necessary for the SKF- or forskolin-evoked $\mathrm{Ca}^{2+}$ responses. Indeed, inositol phosphate (IP) levels in D1HEK293 cells increased continually following addition of the muscarinic receptor agonist as previously noted [24] (fig. 3e). However, addition of the D1R agonist SKF81297 did not stimulate further increases in the IP levels compared to incubation with CCL alone (fig. 3e).

\section{D1R Stimulation Enhances Efficacy of $\mathrm{Ca}^{2+}$ Store Mobilization}

Stimulation of D1Rs also more effectively mobilized internal $\mathrm{Ca}^{2+}$ stores than reapplication of priming agonist (fig. 4a). This effect was observed in experiments in which D1HEK293 cells were washed with $\mathrm{Ca}^{2+}$-free HBS after priming with CCL, and CCL was re-applied 2-4 min later, followed by D1/5R agonist. Compared to the initial CCL-evoked $\mathrm{Ca}^{2+}$ transients, the second round of CCL application evoked much smaller responses both with respect to size and frequency (i.e. only 9 of 46, or $20 \%$ of randomly selected cells responded). In contrast, the $\mathrm{Ca}^{2+}$ responses evoked by subsequent application of SKF81297 significantly exceeded that of the second CCL response (i.e. $45 / 46$, or $98 \%$ of cells randomly selected responded). Receptor desensitization did not seem to play

Fig. 4. D1R stimulation enhances the efficacy of intracellular $\mathrm{Ca}^{2+}$ store mobilization. a D1HEK293 cells were perfused with $\mathrm{Ca}^{2+}$ free HBS after priming with CCL, and CCL reapplied 2 to $4 \mathrm{~min}$ later, followed by SKF. b, c SKF was applied either after (b) or before (c) a suboptimal dose of ATP $(2 \mu \mathrm{M})$ that alone is unable to elicit a detectable $\mathrm{Ca}^{2+}$ transient. 
a major role in the weak $\mathrm{Ca}^{2+}$ transients evoked by the second round of CCL application since significant differences between the initial and second CCL-evoked responses were not detected when similar experiments were performed in $\mathrm{Ca}^{2+}$-containing $\mathrm{HBS}$ (data not shown). Also consistent with the idea that D1R stimulation enhances intracellular $\mathrm{Ca}^{2+}$ store mobilization, SKFevoked responses in cells primed with a dose of ATP $(2 \mu \mathrm{M})$ that is insufficient to evoke detectable $\mathrm{Ca}^{2+}$ transients (fig. 4b). Similarly, pretreatment of cells with SKF 'revealed' $\mathrm{Ca}^{2+}$ transients in cells stimulated with the low dose of ATP (fig. 4c).

D1R Agonists Potentiate Group I mGluR-Evoked $\mathrm{Ca}^{2+}$ Responses in Hippocampal Cultures

We next asked whether cAMP/PKA signaling plays a role in $\mathrm{Ca}^{2+}$ transients regulated by $\mathrm{D} 1 \mathrm{R}-\mathrm{G}_{\mathrm{q} / 11}$ crosstalk in neurons. As in the D1 HEK293 cells (fig. 4c), pre-treatment of hippocampal cultures with D1R agonist amplified the $\mathrm{Ca}^{2+}$ responses evoked by subsequent application of the $\mathrm{G}_{\mathrm{q} / 11}$-coupled (group I) mGluR agonist DHPG (10 $\mu \mathrm{M})$. For example, $\mathrm{Ca}^{2+}$ oscillations were rarely detected in response to DHPG ( $n=2$ of 20 cells) (fig. 5a, b). In the presence of SKF91297 (1 $\mu \mathrm{M})$, however, the group I mGluR agonist frequently generated $\mathrm{Ca}^{2+}$ oscillations, either as baseline spikes or superimposed on an elevated baseline ( $n=6$ of 9 cells) (fig. $5 b-d$ ). We then compared the DHPG responses in cells pretreated with SKF81297, a full agonist to those pretreated a partial D1R agonist SKF38959 [6]. Pretreatment with the D1R agonist SKF38959 $(1 \mu \mathrm{M})$ also altered both the time course as well as the overall shape of the DHPG-evoked responses. Indeed, in the presence of SKF38959, DHPG primarily stimulated $\mathrm{Ca}^{2+}$ oscillations ( $n=17$ of 20 cells) (fig. 5b, e, f). Addition of the voltage-gated sodium channel blocker tetrodotoxin $(1 \mu \mathrm{M})$ during the train of $\mathrm{Ca}^{2+}$ oscillations, quenched the responses (fig. 5e). Further, pretreatment with the PKA inhibitor KT5720 blocked the DHPG-evoked oscillations (fig. 5b, f).

\section{Discussion}

The findings presented here suggest that coupling to Gs- and cAMP-mediated PKA activation are essential components of dopamine D1R-regulated $\mathrm{Ca}^{2+}{ }_{\mathrm{i}}$ transients. Further, these studies suggest that Gs-linked GPCRevoked $\mathrm{Ca}_{\mathrm{i}}{ }^{2+}$ release could be a general phenomenon since the magnitude and latency of the $\mathrm{Ca}^{2+}$ transients stimulated by forskolin, isoproterenol, and SKF81297 were comparable. Indeed, cAMP plays a crucial role in the ability of Gs-linked receptors for adenosine and parathyroid hormone to activate $\mathrm{Ca}^{2+}{ }_{\mathrm{i}}$ release [25-28]. However, our studies also indicated that while necessary, Gs coupling and PKA stimulation are not sufficient for the D1R- or forskolin-evoked $\mathrm{Ca}^{2+}$ responses. Concurrent $\mathrm{G}_{\mathrm{q} / 11}$-linked receptor activation was also required. In neurons, we found that the ability of SKF81297 and SKF38959, full and partial D1R agonists, respectively, to promote $\mathrm{G}_{\mathrm{q} / 11^{-}}$-coupled receptor-evoked $\mathrm{Ca}^{2+}$ oscillations depended on PKA activation.

Ongoing PLC activity has also been implicated in crosstalk between $\mathrm{G}_{\mathrm{i} / \mathrm{o}}$-coupled and $\mathrm{G}_{\mathrm{q}}$-linked receptors $[28,29]$, with the enhanced $\mathrm{Ca}^{2+}$ responses attributed to the allosteric stimulation of PLC by $G_{i / o}$ liberated $\beta \gamma \mathrm{G}$ protein subunits [28, 30-32]. In contrast, measurements of IP levels in D1 HEK293 cells did not reveal a stimulatory effect of SKF81297 activation of D1Rs on PLC. The observation that forskolin was also effective in evoking $\mathrm{Ca}^{2+}{ }_{\mathrm{i}}$ release in the presence of $\mathrm{G}_{\mathrm{q} / 11 \text {-coupled receptor stimulation would suggest that }}$ Gs-coupled receptor stimulation of PLC, even if via liberated $\beta \gamma$ subunits, is not necessary for the robust $\mathrm{Ca}^{2+}$ responses detected. However, our experiments do not rule out a transient enhancement in PLC activity after addition of SKF81297. The ability of U73122 to block, and of washout of priming agonist to abrogate the D1Ror forskolin-evoked $\mathrm{Ca}^{2+}$ responses, further supports the idea that continuous activation of PLC by a heterologous $\mathrm{G}_{\mathrm{q} / 11^{-}}$-linked GPCR is a crucial component of these $\mathrm{Ca}^{2+}$ responses.

There are several downstream sites where cAMP signaling might influence the $\mathrm{Ca}^{2+}{ }_{\mathrm{i}}$ levels $[33,34]$. For example, cAMP is known to activate the epsilon isoform of phospholipase C (PLCE) in a PKA-independent fashion [35]. However, the ability of KT5720 to inhibit the SKF81297-evoked $\mathrm{Ca}^{2+}$ release ruled out a mechanism involving CAMP activation of PLC $\varepsilon$. Alternatively, PKAmediated phosphorylation of $\mathrm{IP}_{3}$ Rs could play a role in the SKF81297- and forskolin-activated responses since DA stimulates phosphorylation of $\mathrm{IP}_{3} \mathrm{Rs}$ in brain slices [36], and PKA phosphorylation of $\mathrm{IP}_{3}$ Rs increases channel sensitivity to $\mathrm{IP}_{3}$ and open probability [36-38]. RTPCR analysis indicates that D1HEK293 cells endogenously express type I and II IP 3 Rs (data not shown), whereas hippocampal neurons express mainly type I receptors, although type III IP ${ }_{3}$ Rs are also present $[36,39]$. Even minor increases in cAMP reportedly result in maximal levels of type I IP ${ }_{3} \mathrm{R}$ phosphorylation [40]. Hence, if PKA phosphorylation of $\mathrm{IP}_{3} \mathrm{Rs}$ is involved in the D1R- 

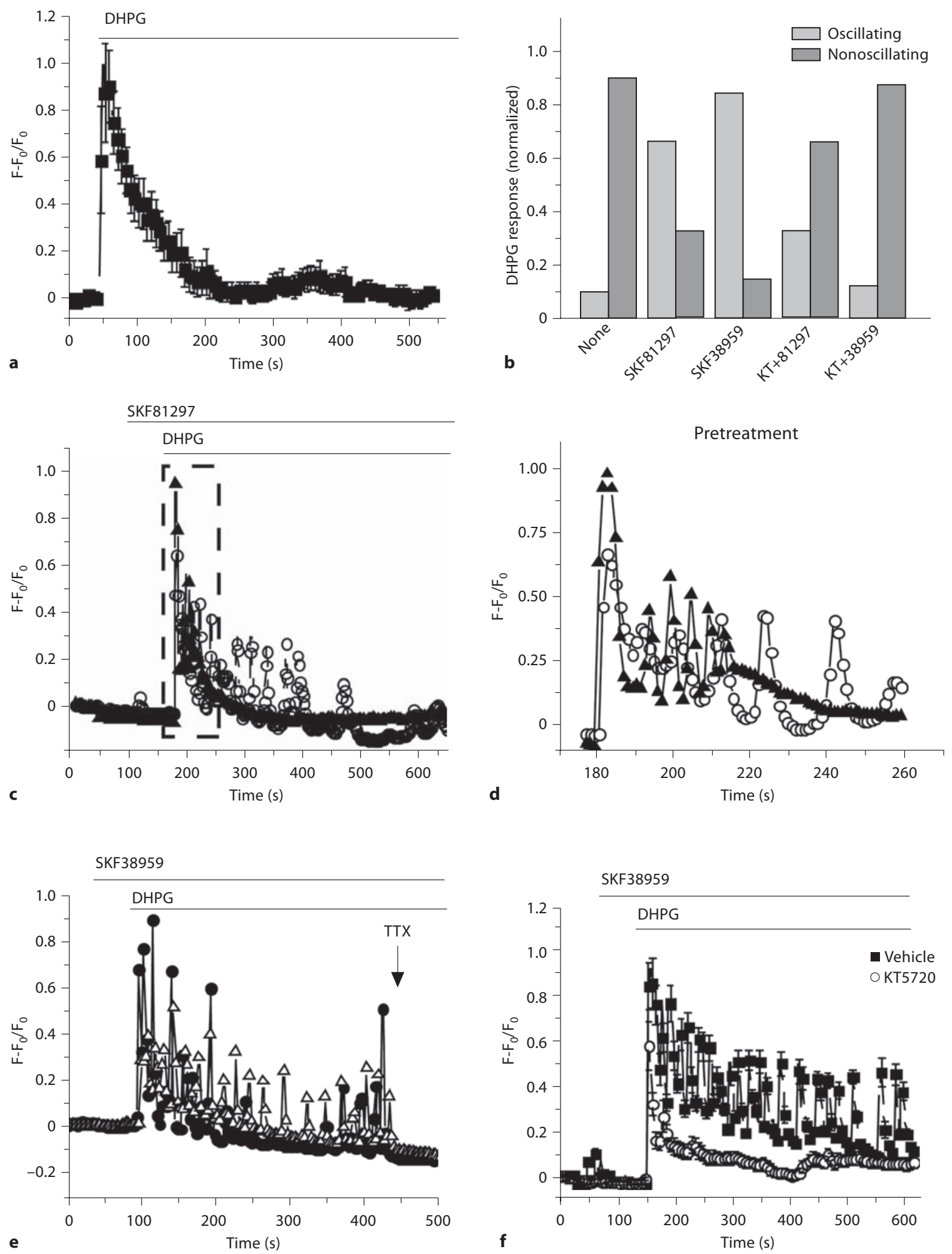
and forskolin-evoked $\mathrm{Ca}^{2+}$ transients, a low threshold might account for the equivalent efficacy of nanomolar and micromolar levels of SKF81297 in promoting $\mathrm{Ca}^{2+}$ release in D1HEK293. Similarly, phosphorylation of type I IP ${ }_{3}$ Rs by PKA could potentially account for the ability of SKF91297 to potentiate the ATP-evoked $\mathrm{Ca}^{2+}$ responses in D1 HEK293 without significantly increasing $\mathrm{IP}_{3}$ production $[41,42]$.

The molecular mechanisms underlying $\mathrm{Ca}^{2+}$ oscillations are thought to be diverse ranging from fluxes in levels of $\mathrm{IP}_{3}, \mathrm{IP}_{3} \mathrm{R}$ phosphorylation and de-phosphorylation, to $\mathrm{Ca}^{2+}$ entry via the plasma membrane [43]. The ability of dopamine presumably via D1Rs to promote

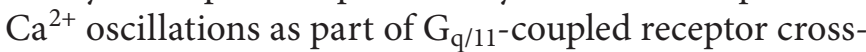
talk paradigm has also been observed in striatal medium spiny neurons in culture, but the signaling mechanism was not worked out [7]. Our studies in hippocampal neurons with SKF81297 and SKF38959 suggest that the ability of D1R agonists to promote group I mGluR stimulated $\mathrm{Ca}^{2+}$ oscillations involves PKA signaling. Consistent with this, PKA phosphorylation of type $\mathrm{I} \mathrm{IP}_{3}$ Rs lowers the threshold for $\mathrm{IP}_{3}$ generated $\mathrm{Ca}^{2+}$ oscillations in non-neuronal cell types [41,44]. Indeed, elevated cAMP levels are also reported to increase the frequency of $\mathrm{Ca}^{2+}$ oscillations in neurons [34]. Hence, the SKF81297 promoted oscillations detected might be accounted for by a combination of PKA-mediated phosphorylation of $\mathrm{IP}_{3} \mathrm{Rs}$ to increase channel open probability, and $\mathrm{Ca}^{2+}$-mediated negative feedback to bring about $\mathrm{IP}_{3} \mathrm{R}$ desensitization [45]. Studies in heterologous cells suggest that mGluR5 surface levels regulate the frequency of $\mathrm{Ca}^{2+}$ oscillations

Fig. 5. D1R stimulation enhances DHPG-generated $\mathrm{Ca}^{2+}$ oscillations in hippocampal neurons. a $\mathrm{Ca}^{2+}$ transient evoked by DHPG $(10 \mu \mathrm{M})$. Shown is the average $(\mathrm{n}=12)$ response detected in 5 independent experiments. b Normalized fraction of oscillatory (light bars) and nonoscillatory (dark bars) DHPG responses detected in neurons either not pretreated with any agents (none), or pretreated with SKF81297 or SKF38959 (both at $1 \mu \mathrm{M}$ ), either alone or 10-15 min after KT5720 (KT, 66 nM). c, d Representative oscillatory DHPG responses detected in neurons treated with SKF81297 (1 MM). The time course within the hatched box in $\mathbf{c}$ is expanded in d. e Representative oscillatory DHPG responses detected in neurons treated with SKF38959 $(1 \mu \mathrm{M})$. Arrow indicates time of TTX $(1 \mu \mathrm{M})$ application. $\mathbf{f}$ Average DHPG response in neurons $(\mathrm{n}=12)$ pretreated with KT5720 (66 nM) for 10-15 min prior to addition of SKF38959 is shown in open circles, whereas average response detected in neurons $(n=6)$ treated with SKF38959 is shown in filled squares.

cAMP and D1R Calcium Signaling
[46], and that mGluR1 can potentially elevate cAMP as well as intracellular $\mathrm{Ca}^{2+}$ levels [47]. Alternatively, it is conceivable that either altered mGluR1/5 surface expression or G protein coupling are involved in the D1R-promoted oscillations. On the other hand, D1R agonist-specific signaling mechanism(s) might be involved in the oscillatory $\mathrm{Ca}^{2+}$ responses detected. Indeed, the oscillatory effect on the DHPG-evoked responses was more consistently observed in neurons treated with SKF38959. Unlike SKF81297, SKF38959 is not a potent activator of adenylyl cyclase $[6,19]$. SKF38959 is considered a partial agonist, and has been extensively utilized to pharmacologically characterize a putative PLC-linked D1-like receptor that has yet to be cloned [19, 20,48]. Intriguingly, more recent studies suggest that SKF38959 preferentially activates D1Rs involved in a heterodimeric complex with $\mathrm{G}_{\mathrm{i} / \mathrm{o}}$-linked D2 DA receptors $[9,49]$. If a D1/D2 heterodimer is required for SKF38959 binding, the robust oscillatory effect of this partial agonist on the DHPG responses might be attributed to direct or allosteric stimulation of PLC in combination with positive (e.g. PKA-mediated) and negative (e.g. $\mathrm{Ca}^{2+}$-mediated) feedback mechanisms $[28,30-32,50]$.

Studies in model systems suggest that $\mathrm{Ca}^{2+}$ oscillations potentially provide a unique cue for regulating the efficiency and specificity of gene transcription [51]. The present findings raise the possibility that the $\mathrm{Ca}^{2+}$ oscillations promoted by $\mathrm{D} 1 \mathrm{R}$ and $\mathrm{G}_{\mathrm{q} / 11}$-linked mGluR crosstalk might impact gene transcription in neurons, albeit in a PKA-dependent fashion. Indeed, both D1R-mediated phosphorylation of cAMP response element binding protein (CREB) transcription factor and $\mathrm{G}_{\mathrm{q} / 11}$-linked mGluR signaling are implicated in drug addiction and reward mechanisms [52-54].

\section{Acknowledgements}

This work was supported by the NIH MH063271 (C.B.) and a NARSAD Independent Investigator Award (C.B.). We thank Balakrishna Prasad and Shalini Padmanabhan for neuronal cultures, and Brian Murphy and Neha Arora for technical assistance. 


\section{References}

1 Missale C, Nash SR, Robinson SW, Jaber M, Caron MG: Dopamine receptors: from structure to function. Physiol Rev 1998;78:189225.

-2 Smiley JF, Levey AI, Ciliax BJ, Goldman-Rakic PS: D1 dopamine receptor immunoreactivity in human and monkey cerebral cortex: predominant and extrasynaptic localization in dendritic spines. Proc Natl Acad Sci USA 1994;91:5720-5724.

$\checkmark 3$ Paspalas CD, Goldman-Rakic PS: Presynaptic D1 dopamine receptors in primate prefrontal cortex: target-specific expression in the glutamatergic synapse. J Neurosci 2005; 25:1260-1267.

4 Goldman-Rakic PS, Muly EC, III, Williams $\mathrm{GV}: \mathrm{D}(1)$ receptors in prefrontal cells and circuits. Brain Res Brain Res Rev 2000;31:295301.

5 Bergson C, Mrzljak L, Smiley JF, Pappy M, Levenson R, Goldman-Rakic PS: Regional, cellular, and subcellular variations in the distribution of D1 and D5 dopamine receptors in primate brain. J Neurosci 1995;15: 7821-7836.

6 Arnt J, Hyttel J, Sanchez C: Partial and full dopamine D1 receptor agonists in mice and rats: relation between behavioural effects and stimulation of adenylate cyclase activity in vitro. Eur J Pharmacol 1992;213:259-267.

7 Tang TS, Bezprozvanny I: Dopamine receptor-mediated $\mathrm{Ca}(2+)$ signaling in striatal medium spiny neurons. J Biol Chem 2004;279: 42082-42094.

$\checkmark 8$ Lezcano N, Bergson C: D1/D5 dopamine receptors stimulate intracellular calcium release in primary cultures of neocortical and hippocampal neurons. J Neurophysiol 2002; 87:2167-2175

$\checkmark 9$ Rashid AJ, So CH, Kong MM, et al: D1-D2 dopamine receptor heterooligomers with unique pharmacology are coupled to rapid activation of $\mathrm{Gq} / 11$ in the striatum. Proc Natl Acad Sci USA 2007;104:654-659.

>10 Mahan LC, Burch RM, Monsma FJ Jr, Sibley DR: Expression of striatal D1 dopamine receptors coupled to inositol phosphate production and $\mathrm{Ca}^{2+}$ mobilization in Xenopus oocytes. Proc Natl Acad Sci USA 1990;87: 2196-2200.

-11 Ming Y, Zhang H, Long L, Wang F, Chen J, Zhen X: Modulation of $\mathrm{Ca}^{2+}$ signals by phosphatidylinositol-linked novel D1 dopamine receptor in hippocampal neurons. J Neurochem 2006;98:1316-1323.

-12 Redmond L, Kashani AH, Ghosh A: Calcium regulation of dendritic growth via CaM kinase IV and CREB-mediated transcription. Neuron 2002;34:999-1010.

$\checkmark 13$ Malinow R, Malenka RC: AMPA receptor trafficking and synaptic plasticity. Annu Rev Neurosci 2002;25:103-126.
14 Roussel C, Erneux T, Schiffmann SN, Gall D: Modulation of neuronal excitability by intracellular calcium buffering: from spiking to bursting. Cell Calcium 2006;39:455-466.

15 Sudhof TC: The synaptic vesicle cycle. Annu Rev Neurosci 2004;27:509-547.

16 West AE, Chen WG, Dalva MB, et al: Calcium regulation of neuronal gene expression. Proc Natl Acad Sci USA 2001;98:1102411031.

17 Calderon DP, Leverkova N, Peinado A: $\mathrm{Gq} / 11$-induced and spontaneous waves of coordinated network activation in developing frontal cortex. J Neurosci 2005;25:17371749.

18 Otani S, Auclair N, Desce JM, Roisin MP, Crepel F: Dopamine receptors and groups I and II mGluRs cooperate for long-term depression induction in rat prefrontal cortex through converging postsynaptic activation of MAP kinases. J Neurosci 1999;19:97889802

19 Jin LQ, Goswami S, Cai G, Zhen X, Friedman E: SKF83959 selectively regulates phosphatidylinositol-linked D1 dopamine receptors in rat brain. J Neurochem 2003;85:378-386.

20 Panchalingam S, Undie AS: Physicochemical modulation of agonist-induced [35s] GTPgammaS binding: implications for coexistence of multiple functional conformations of dopamine D1-like receptors. J Recept Signal Transduct Res 2005;25:125-146.

21 Ali MK, Bergson C: Elevated intracellular calcium triggers recruitment of the receptor cross-talk accessory protein calcyon to the plasma membrane. J Biol Chem 2003;278: 51654-51663.

22 Islam M, Akhtar RA: Epidermal growth factor stimulates phospholipase cgammal in cultured rabbit corneal epithelial cells. Exp Eye Res 2000;70:261-269.

23 Wang Q, Mullah BK, Robishaw JD: Ribozyme approach identifies a functional association between the $\mathrm{G}$ protein betalgamma7 subunits in the beta-adrenergic receptor signaling pathway. J Biol Chem 1999;274 17365-17371.

24 Mundell SJ, Benovic JL: Selective regulation of endogenous $\mathrm{G}$ protein-coupled receptors by arrestins in HEK293 cells. J Biol Chem 2000;275:12900-12908.

25 Tovey SC, Goraya TA, Taylor CW: Parathyroid hormone increases the sensitivity of inositol trisphosphate receptors by a mechanism that is independent of cyclic AMP. Br J Pharmacol 2003;138:81-90

26 Short AD, Taylor CW: Parathyroid hormone controls the size of the intracellular $\mathrm{Ca}(2+)$ stores available to receptors linked to inositol trisphosphate formation. J Biol Chem 2000 275:1807-1813.
27 Buckley KA, Wagstaff SC, McKay G, et al: Parathyroid hormone potentiates nucleotide-induced $\left[\mathrm{Ca}^{2+}\right]_{\mathrm{i}}$ release in rat osteoblasts independently of $\mathrm{Gq}$ activation or cyclic monophosphate accumulation. A mechanism for localizing systemic responses in bone. J Biol Chem 2001;276:9565-9571.

28 Werry TD, Wilkinson GF, Willars GB: Mechanisms of cross-talk between G-protein-coupled receptors resulting in enhanced release of intracellular $\mathrm{Ca}^{2+}$. Biochem J 2003; 374:281-296.

29 Werry TD, Christie MI, Dainty IA, Wilkinson GF, Willars GB: $\mathrm{Ca}(2+)$ signalling by recombinant human CXCR2 chemokine receptors is potentiated by $\mathrm{P} 2 \mathrm{Y}$ nucleotide receptors in HEK cells. Br J Pharmacol 2002; 135:1199-1208.

30 Quitterer U, Lohse MJ: Crosstalk between Galpha(i)- and Galpha(q)-coupled receptors is mediated by Gbetagamma exchange. Proc Natl Acad Sci USA 1999;96:10626-10631.

- 31 Yeo A, Samways DS, Fowler CE, GunnMoore F, Henderson G: Coincident signalling between the Gi/Go-coupled delta-opioid receptor and the Gq-coupled $\mathrm{m} 3$ muscarinic receptor at the level of intracellular free calcium in SH-SY5Y cells. J Neurochem 2001;76:1688-1700.

32 Chan JS, Lee JW, Ho MK, Wong YH: Preactivation permits subsequent stimulation of phospholipase C by G(i)-coupled receptors. Mol Pharmacol 2000;57:700-708.

33 Zaccolo M, Pozzan T: CAMP and $\mathrm{Ca}^{2+}$ interplay: a matter of oscillation patterns. Trends Neurosci 2003;26:53-55.

>34 Gorbunova YV, Spitzer NC: Dynamic interactions of cyclic AMP transients and spontaneous $\mathrm{Ca}(2+)$ spikes. Nature 2002;418:9396.

35 Schmidt M, Evellin S, Weernink PA, et al: A new phospholipase-C-calcium signalling pathway mediated by cyclic AMP and a Rap GTPase. Nat Cell Biol 2001;3:1020-1024.

\$36 Tang TS, Tu H, Wang Z, Bezprozvanny I: Modulation of type 1 inositol $(1,4,5)$-trisphosphate receptor function by protein kinase a and protein phosphatase lalpha. J Neurosci 2003;23:403-415.

37 Bruce JI, Straub SV, Yule DI: Crosstalk between cAMP and $\mathrm{Ca}^{2+}$ signaling in non-excitable cells. Cell Calcium 2003;34:431-444.

>38 Tu H, Tang TS, Wang Z, Bezprozvanny I: Association of type 1 inositol 1,4,5-trisphosphate receptor with AKAP9 (Yotiao) and protein kinase A. J Biol Chem 2004;279: 19375-19382.

39 Jacob SN, Choe CU, Uhlen P, DeGray B, Yeckel MF, Ehrlich BE: Signaling microdomains regulate inositol 1,4,5-trisphosphatemediated intracellular calcium transients in cultured neurons. J Neurosci 2005;25:28532864. 
40 Wojcikiewicz RJ, Luo SG: Phosphorylation of inositol 1,4,5-trisphosphate receptors by cAMP-dependent protein kinase: type I, II, and III receptors are differentially susceptible to phosphorylation and are phosphorylated in intact cells. J Biol Chem 1998;273: 5670-5677.

41 Wagner LE, Li WH, Joseph SK, Yule DI: Functional consequences of phosphomimetic mutations at key cAMP-dependent protein kinase phosphorylation sites in the type 1 inositol 1,4,5-trisphosphate receptor. J Biol Chem 2004;279:46242-46252.

42 Brown DA, Bruce JI, Straub SV, Yule DI: cAMP potentiates ATP-evoked calcium signaling in human parotid acinar cells. J Biol Chem 2004;279:39485-39494.

-43 Sneyd J, Tsaneva-Atanasova K, Yule DI, Thompson JL, Shuttleworth TJ: Control of calcium oscillations by membrane fluxes. Proc Natl Acad Sci USA 2004;101:13921396.
44 Chatton JY, Cao Y, Liu H, Stucki JW: Permissive role of cAMP in the oscillatory $\mathrm{Ca}^{2+}$ response to inositol 1,4,5-trisphosphate in rat hepatocytes. Biochem J 1998;330:1411-1416.

45 Bezprozvanny I: The inositol 1,4,5-trisphosphate receptors. Cell Calcium 2005;38:261272.

46 Nash MS, Schell MJ, Atkinson PJ, Johnston NR, Nahorski SR, Challiss RA: Determinants of metabotropic glutamate receptor-5mediated $\mathrm{Ca}^{2+}$ and inositol 1,4,5-trisphosphate oscillation frequency: receptor density versus agonist concentration. J Biol Chem 2002;277:35947-35960.

47 Tateyama M, Kubo Y: Dual signaling is differentially activated by different active states of the metabotropic glutamate receptor 1alpha. Proc Natl Acad Sci USA 2006;103:11241128.

48 Wang HY, Undie AS, Friedman E: Evidence for the coupling of $\mathrm{Gq}$ protein to D1-like dopamine sites in rat striatum: possible role in dopamine-mediated inositol phosphate formation. Mol Pharmacol 1995;48:988-994.
49 Lee SP, So CH, Rashid AJ, et al: Dopamine D1 and D2 receptor Co-activation generates a novel phospholipase C-mediated calcium signal. J Biol Chem 2004;279:35671-35678.

50 Cordeaux Y, Hill SJ: Mechanisms of crosstalk between G-protein-coupled receptors. Neurosignals 2002;11:45-57.

51 Dolmetsch RE, Xu K, Lewis RS: Calcium oscillations increase the efficiency and specificity of gene expression. Nature 1998;392: 933-936.

52 Konradi C, Cole RL, Heckers S, Hyman SE: Amphetamine regulates gene expression in rat striatum via transcription factor CREB. J Neurosci 1994;14:5623-5634.

53 Koob GF, Nestler EJ: The neurobiology of drug addiction. J Neuropsychiatry Clin Neurosci 1997;9:482-497.

54 Kalivas PW, Volkow ND: The neural basis of addiction: pathology of motivation and choice. Am J Psychiatry 2005;162:14031413. 